\title{
Organizacja współczesnych systemów wytwarzania
}

https://doi.org/10.33141/po.2005.78.09

\section{Zygmunt Mazur}

Przegląd Organizacji, Nr 7/8 (786/787), 2005, ss. 36-39

www.przegladorganizacji.pl Towarzystwo Naukowe Organizacji i Kierownictwa (TNOiK)

\section{Rola zarządzania produkcją w zarządzaniu organizacją}

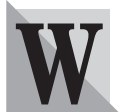

spółcześnie na znaczeniu zyskuje dynamiczne ujęcie organizacji i zachodzących w niej procesów majacych wpływ na koncepcję rozwiązań strukturalnych organizacji przyszłości. Koncepcja orientacji na procesy odpowiada wymaganiom stawianym w paradygmacie zarzadzania XXI wieku [4]. Współczesną rolą zarządzania procesami jest organizacja przebiegu procesów w ujęciu dynamicznym (czasowym) i przestrzennym w sposób powodujący zwiększenie efektywności działań poprzez strukturalizację czynności, działań, decyzji i dokumentacji [2]. Podstawowym kryterium wyboru tej organizacji jest wielkość generowanej wartości dodanej. Jak twierdzi J. Stacewicz, istotny wpływ na kształtowanie się nowoczesnych rozwiązań strukturalnych ma tzw. filozofia procesu, upatrująca istotę racjonalności działań nie w wypreparowanych i egoistycznych działaniach jednostek zmierzających do maksymalizacji swojej satysfakcji, lecz w racjonalności zbiorowej, świadomie działającej na rzecz rozwoju [11]. Stosowanie różnych kryteriów, podziałów, kategorii procesów można traktować jako element nierozłącznie związany z rozwojem teorii zarządzania. Znaczenie przyjętych reguł klasyfikacji procesów ma wpływ na skuteczność osiąganych wyników działania systemu [3].

Podejście procesowe zakłada, że przedsiębiorstwo (jako jedna $\mathrm{z}$ form organizacji) jest całością złożoną z procesów, a proces - całością złożoną z sukcesywnie wykonywanych operacji zmierzających do osiągnięcia założonego celu [1].

Procesowa koncepcja organizacji pozwala wyznaczyć (zidentyfikować) w przedsiębiorstwie między in-

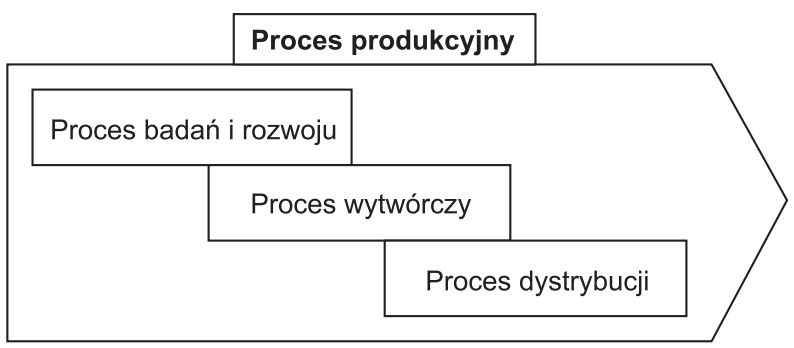

Rys. 1. Umiejscowienie procesu wytwórczego Źródło: opracowanie własne. nymi takie procesy, jak: $\bullet$ marketingowe, $\bullet$ finansowe, $\bullet$ kadrowe, $\bullet$ naukowo-techniczne, $\bullet$ prawne, - produkcji.

Jednym z elementów procesu produkcji jest proces wytwórczy (wytwarzania), którego umiejscowienie w procesie produkcji przedstawia rysunek 1 .

Organizacja i zarządzanie produkcją obejmuje całokształt zagadnień związanych z realizacją zintegrowanego procesu produkcyjnego, czyli formowanie przepływu w czasie i przestrzeni (formowanie struktury elastycznego systemu produkcyjnego) i koordynację działań w systemach produkcyjnych, tzw. zarządzanie przepływem. Zintegrowany proces produkcyjny to strumień działań przygotowawczych, obsługowych, transportowo-magazynowych i sterujących, współdziałających z podstawowym procesem. Zintegrowany proces realizowany jest w systemie produkcyjnym, w którym przebiega transformacja materiałów na wyroby gotowe.

\section{Procesy w systemie wytwarzania}

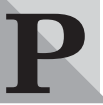

roces wytwarzania realizowany jest w systemie wytwarzania. System wytwarzania to zbiór elementów w zorganizowanej przestrzeni o ustalonych powiązaniach kooperacyjnych między elementami. Działanie w procesach wytwarzania to wykonywanie operacji w określonej kolejności wynikającej z planu operacji. W systemach wytwarzania realizowane są procesy, których podział przedstawia rysunek 2 .

Celem procesów realizowanych w systemie wytwarzania jest tworzenie produktów wysokiej jakości we właściwym czasie minimalnym kosztem. Ich umiejscowienie w czasie całego cyklu realizacji procesu wytwarzania przedstawia schematycznie rysunek 3 . Procesy pomocnicze to grupa procesów wspomagających i zabezpieczających funkcjonowanie podstawowego procesu wytwarzania. Zasadniczym celem procesów pomocniczych jest wspieranie działania procesów podstawowych.

Zorientowanie na procesy, w przypadku systemu wytwarzania, polega na wyłonieniu dla każdej grupy wyrobów podobnych zintegrowanego procesu wytwarzania. Zintegrowany proces wytwarzania to zbiór współbieżnych i współzależnych procesów, których celem jest realizacja wyrobów o określonych parametrach. Schemat zintegrowanego procesu wytwarzania przedstawia rysunek 4 . 


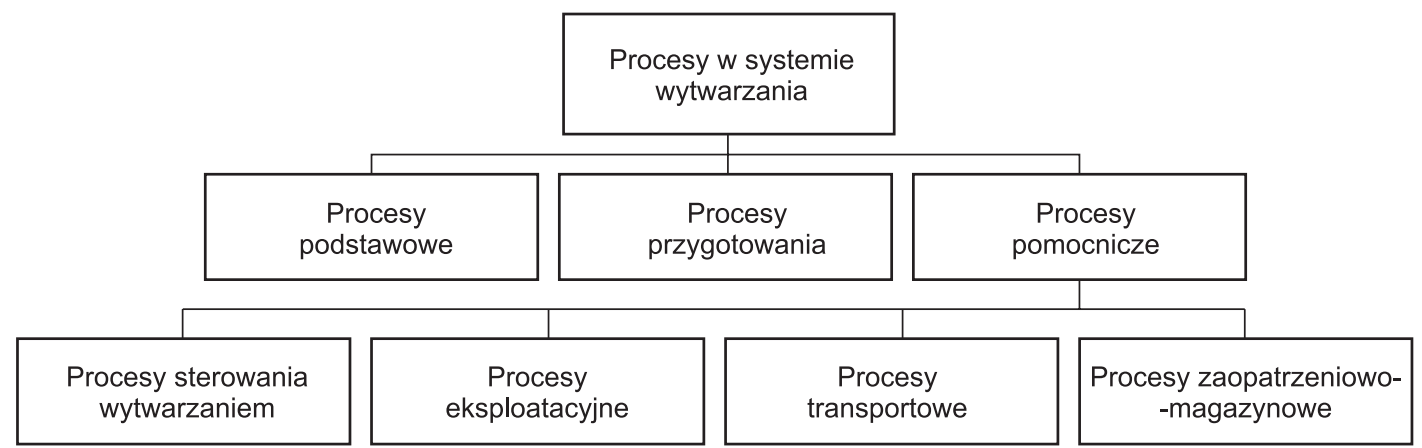

Rys. 2. Procesy w systemie wytwarzania

Źródło: opracowanie własne.
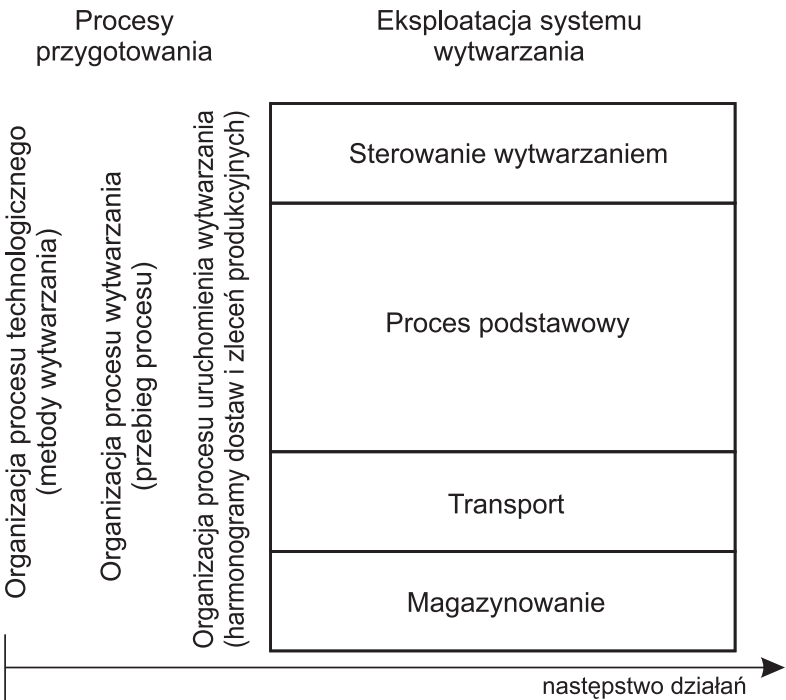

Rys. 3. Współzależność procesów w systemie wytwarzania

Źródło: opracowanie własne.

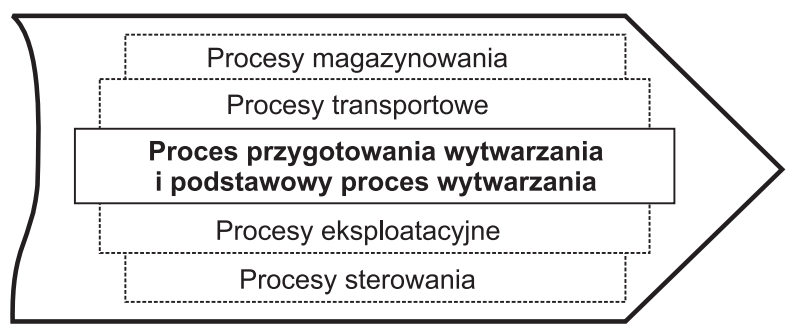

Rys. 4. Zintegrowany proces wytwarzania Źródło: opracowanie własne.

Proces, którego atrybutem jest integracja, musi wiązać we współdziałaniu poszczególne elementy składowe systemu w wyniku zorganizowania procesowego. Zintegrowany strumien działań dających w efekcie produkt odpowiadający zapotrzebowaniu klientów realizowany powinien być $\mathrm{w}$ strukturze procesowej. Procesy realizowane $\mathrm{w}$ systemie wytwarzania są organizowane i koordynowane w przestrzeni i w czasie, posiadają więc swoją strukturę przestrzenną i czasową.
Formowanie przepływu tych procesów dotyczyć może działań, które przedstawiono na rysunku 5.

Sposób koordynacji procesów w systemie wytwarzania uzależniony jest od stosowanych form przepływu procesu wytwarzania. W systemie wytwarzania mogą występować formy przepływów procesów, których charakterystykę można przedstawić schematycznie tak, jak to pokazano na rysunku 6.

Przepływy nie mogą być statycznym obrazem, muszą one przedstawiać zachodzące $\mathrm{w}$ toku procesu zmiany w czasie i przestrzeni (uwzględniać muszą dynamikę procesu). Przepływy muszą obrazować procesy transformacji zachodzące $\mathrm{w}$ systemie wytwarzania. Dynamika zmian przepływów zachodzących w systemie wymusza elastyczność jego struktury. Koordynacja przepływów mająca na celu zapewnienie ustalonych terminów realizacji zadań zależy od typu sytuacji produkcyjnej i czasu przeznaczonego na realizację zadań.

Typ sytuacji produkcyjnej określa, jaka zasada realizacji procesów produkcyjnych została przyjęta. Wyróżnić można dwie sytuacje: • realizacja na zamówienie, $\bullet$ realizacja do magazynu.

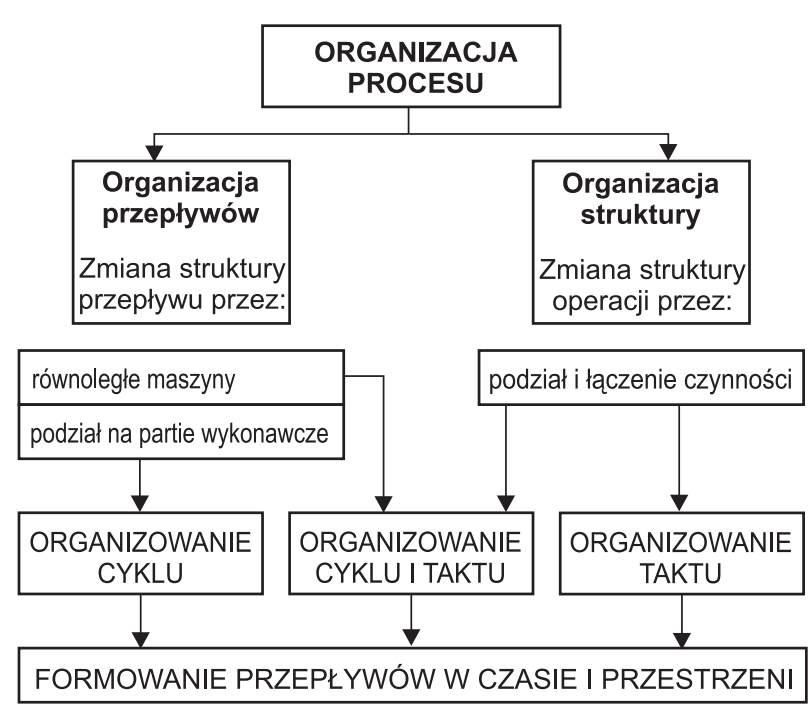

Rys. 5. Organizacja procesów w systemie wytwarzania

Źródło: opracowanie własne. 


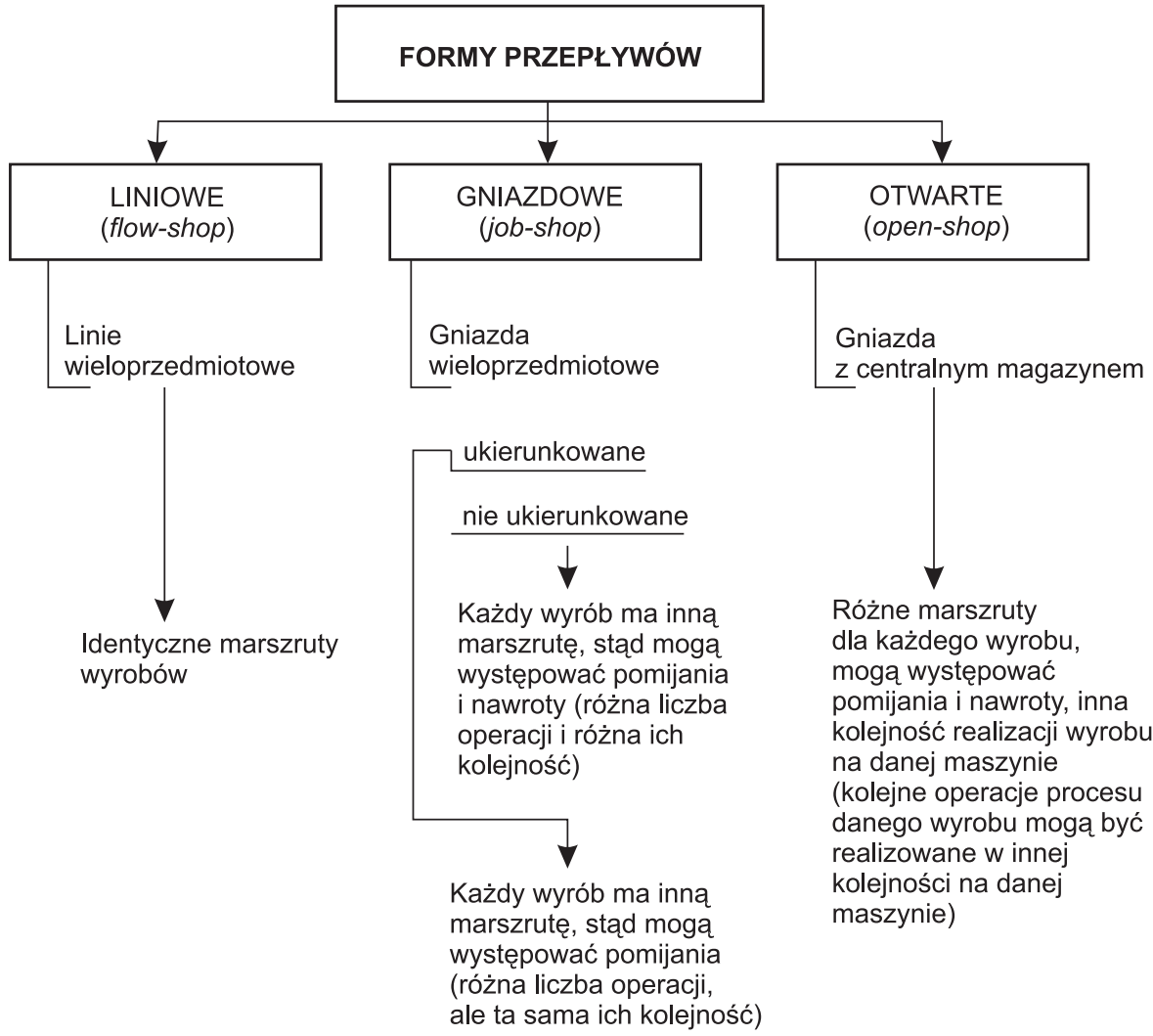

Rys. 6. Formy przepływów

Źródło: opracowanie własne.

\section{Nowoczesne systemy wytwarzania}

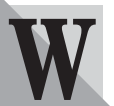
spółczesne i przyszłe systemy wytwarzania powinny posiadać zdolność adaptacyjną w stosunku do zmian zewnętrznych i wewnętrznych oraz wysoką elastyczność wyrażającą się:

- otwartością na zmiany:

$\checkmark$ szybką reakcją na zaistniałe sytuacje (potrzeby),

$\checkmark$ odpornościa na zakłócenia,

- łatwością dostosowywania się do przewidywanych warunków:

$\checkmark$ adaptacją do nowych wyrobów,

$\checkmark$ adaptacją do nowych układów produkcyjnych,

$\checkmark$ adaptacją do terminów realizacji.

Elastyczność współczesnych systemów wytwarzania musi dać możliwość działania na indywidualne życzenie klienta.

Biorac pod uwagę przedstawione w literaturze np. $[10,8,5]$ struktury systemów wytwarzania (holoniczne, zwinne) i ich cechy charakterystyczne, stwierdzić można, że chodzi o te same struktury określone różnymi nazwami. Zawsze system wytwarzania to zbiór elementów (modułów, segmentów, oddziałów) łączonych siecią kooperacyjna.

Kooperacja określona jest przez realizowane procesy wytwarzania (przepływy). Kooperacja tworzy sieć powiązań zmieniającą się wraz ze zmianą przepływów. Daje to możliwość zmiennych konfiguracji systemu wytwarzania. Element systemu wytwarzania należy rozumieć jako stanowisko lub zbiór stanowisk realizujących tę samą operację technologiczną. Systemy wy- twarzania o takiej konfiguracji mogą się przystosowywać do zmian w otoczeniu (nowe produkty, nowe procesy, nowe technologie, nowe organizacje itp.) i są otwarte na zmiany oraz elastyczne w reagowaniu na przystosowanie się do tych zmian.

Możliwość adaptacji do nowych warunków zwiększa się poprzez wprowadzenie możliwości kooperacji zewnętrznej pomiędzy elementami z różnych systemów wytwarzania znajdujących się w organizacji fraktalnej. Charakterystykę struktury fraktalnej, będącej podstawą funkcjonowania nowoczesnej firmy, przedstawił K. Perechuda [9]. Jest to organizacja posiadająca charakter elastyczny, dynamiczny, sieciowy i procesowy.

Zdolności adaptacyjne zapewniać mogą organizacje modularne dające elastyczność poprzez zmiany struktury kooperacyjnej.

Struktury te tworzy się $\mathrm{w}$ formie struktury modułów łączonych $\mathrm{w}$ danej sytuacji siecia kooperacji wynikajaca $\mathrm{z}$ realizowanych procesów. Sieć kooperacji może być: • wewnętrzna (w danej organizacji), $\bullet$ zewnętrzna (zgodnie z filozofią $X$-engineering).

Systemy wytwarzania posiadające strukturę organizacji modularnej można nazywać adaptacyjnymi systemami wytwarzania. Adaptacyjne systemy wytwarzania to struktury procesowe z elastycznymi zespołami wytwarzania dostosowującymi się do zaistniałej sytuacji (rysunek 7).

Sa to logiczne, dynamiczne struktury wytwarzania. Są one zbiorem elementów realizujących kolejne etapy procesu, połączonych logistyczną siecią kooperacji. Kooperacja określa, gdzie lokować dany fragment procesu wytwarzania, w jakim czasie i jakiej wielkości.

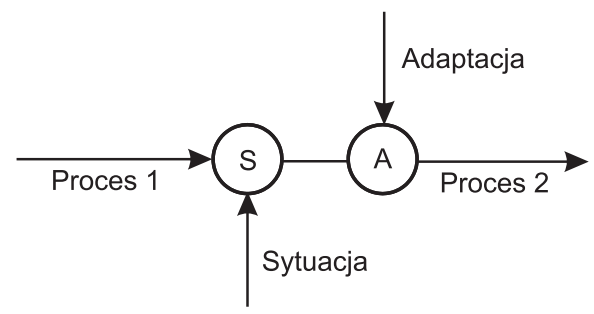

Rys. 7. Proces adaptacji

Źródło: opracowanie własne. 


\section{Ewolucja systemów wytwarzania}

$\mathbf{E}$ wolucja struktur systemów wytwarzania wynika z potrzeby dostosowywania się do aktualnych i przewidywanych warunków rynkowych. Ewolucja ta przebiega od „sztywnych” struktur $\mathrm{w}$ formie stałych gniazd i linii do adaptacyjnych systemów wytwarzania występujących w formie logicznych, dynamicznych struktur wytwarzania [6]. Ewolucja do najnowszych form przebiega poprzez struktury przejściowe elastyczne, w formie linii i gniazd wieloprzedmiotowych [7].

Dostosowywanie form struktur do nowych sytuacji nazywać można restrukturyzacją. Restrukturyzacja systemu wytwarzania pozwala na przystosowanie go do zmieniających się potrzeb klientów przez jego doskonalenie prowadzace do adaptacyjnego systemu wytwarzania, w formie logicznych struktur wytwarzania. Restrukturyzacja przebiegać powinna według następującego schematu działania: • identyfikacja procesów w systemie wytwarzania (selekcja procesów), - odwzorowanie każdego procesu wytwarzania (opis marszruty technologicznej, czasów trwania operacji, parametrów procesu), $\bullet$ formowanie przepływów procesu (określenie parametrów przepływu), • ustalenie zasad kooperacji, • określenie zasad kooperacji procesu (organizacja form przepływu), • wdrożenie zmiany.

Procesy rozumiane jako sekwencyjny ciąg operacji tworzą dynamiczny obraz systemu wytwarzania. Orientacja na procesy pozwala więc na efektywniejsze zarządzanie systemem produkcyjnym.

dr inż. Zygmunt Mazur

Wydział Zarządzania AGH w Krakowie Zakład Zarządzania Produkcją i Techniką

\section{BIBLIOGRAFIA}

[1] BRILMAN J., Nowoczesne koncepcje i metody zarzadzania, PWE, Warszawa 2002.

[2] CIEŚLIŃSKI W.,Zarzadzanie procesami, [w:] K. PERECHUDA (red.), Zarzadzanie przedsiębiorstwem przysztości, Placet, Warszawa 2000.

[3] KASIEWICZ S., Zarzadzanie operacyjne $w$ dobie globalizacji, Difin, Warszawa 2002.

[4] OLSZEWSKA K., Orientacja na procesy koncepcja zarzadzania organizacjami XXI wieku, „Przegląd Organizacji" nr 12/2003.

[5] MATUSZEK J. Inżynieria produkcji, Wydawnictwo Politechniki Eódzkiej, Filia w Bielsku Białej, Bielsko Biała 2000. [6] MAZUR Z., DUDEK M., Adaptacyjne systemy wytwarzania, [w:] A. STABRYŁA (red.), Instrumenty i formy organizacyjne procesów zarzadzania $w$ spoteczeństwie informacyjnym, Wydawnictwo AE w Krakowie, Kraków 2004.

[7] MAZUR Z., DUDEK M., OBRZUD J. Procesowa struktura systemu wytwarzania, [w:] M. ROMANOWSKA, M. TROCKI (red.), Podejście procesowe w zarzadzaniu, Tom 2, Wydawnictwo SGH, Warszawa 2004.

[8] MUSZYŃSKI W., BANASZAK Z., Holoniczne koncepcje zarzadzania i sterowania procesami wytwórczymi, [w:] J. SKALIK (red.), Zachowania organizacji wobec zjawisk kryzysowych, Cornetis, Wrocław 2003.

[9] PERECHUDA K. (red.).,Zarzadzanie przedsiebiorstwem przysztości. Koncepcje, modele, metody, Placet, Warszawa 2000.

[10] RUDNICKI J., SIUTA B., Innowacyjność strategii agile, ,Zarządzanie Przedsiębiorstwem” nr 2/2003.

[11] STACEWICZ J., Ewolucja myślenia o przysztości, [w:] Filozofia myślenia o przysztości, RCSS, Warszawa 2002. 